\title{
The Evaluation of the Changes in the Agricultural Sector with Common Economic Indicators in Turkey during the Last Decade
}

\author{
Sibel Tan \\ Çanakkale Onsekiz Mart University, Faculty of Agriculture, 17100, Çanakkale/Turkey \\ Şermin Atak \\ Çanakkale Onsekiz Mart University, Faculty of Economics And Administrative Science at Çanakkale, 17100, Çanakkale/Turkey \\ Ümran Şengül \\ Çanakkale Onsekiz Mart University, Faculty of Economics And Administrative Science at Çanakkale, 17100, Çanakkale/Turkey \\ Sabri Sami Tan \\ Çanakkale Onsekiz Mart University, Faculty of Economics And Administrative Science at Biga, 17100, Çanakkale/Turkey
}

\section{Doi:10.5901/mjss.2015.v6n2s1p588}

\section{Abstract}

Agriculture is an important sector in the Turkish Economy in terms of population and employment, nutrition, agricultural production, domestic consumption, its contribution to industry, national income and balance of payments. By current economic indicators in Turkey, while its share in national income is $9.0 \%$, its share in employment is $23.6 \%$. Although the share of agriculture in GDP decreased in Turkey in the last decade, the rate of growth of agricultural sector increased. Whereas cultivated fields and the number of livestock declined, vegetative production and animal production increased significantly. Moreover, the rate of total employment increased, but the rate of agricultural employment decreased. In addition, the use of machine in agriculture increased and the wage of employees in agriculture increased considerably, as well. On the other hand, agricultural support policies in the last decade witnessed major reforms and important support policies were implemented in many areas. In 2013, the share of agricultural subsidies in gross domestic product increased compared to the previous year and an increase in the 2014 budget was targeted. In this study, agriculture-related indicators in Turkey in the last ten years will be evaluated and the last ten-year change and the reasons of this change will be examined. In the light of these changes, agricultural recommendations in terms of future oriented agricultural plans and programs will be presented.

Keywords: Agricultural Sector, Economic Indicators, Turkey.

\section{Introduction}

A vision of agriculture as a sector practicing only plant and livestock production activities to meet the food and other agriculture-originated product demands of people and providing the surplus to export is a significant deficiency (Erkuş et al., 2005). Agriculture should perform four basic functions while transition from an agriculture-dominated economy to an industrialized economy. Agriculture before all should supply the food demands of country population. Agriculture should create a production surplus to support the required currency demands of export. Agriculture, bearing the capital and labor transfer to other sectors of the economy, should create a demand potential for industrial goods of the country (Cinemre and Kılıç, 2011). Therefore, agriculture always keeps its significance in Turkish economy with regard to population and employment, nutrition, agricultural production, domestic consumption, supports to industry, national income and balance of payments.

Turkey with its geographical position, climate pattern and product diversity has a rich agricultural potential. However, unregistered productions, insufficient activity of producer organizations, unstable agricultural policies and unplanned production models all together create serious problems in the sector. Since a planned production model complying with internal and external demands is not adopted, supply surplus and consequent producer price decreases are observed in some products and supply deficit and consequent imports are observed in others.

On the other hand, labor surplus in agriculture because of machinery use and the decreases in income levels of people living in rural parts of the country rushed up the migrations from the rural to urban sections of the country. Economic indicators revealed that the share of agriculture in GDP and employment has gradually decreased. Compared 
to the numbers in developed EU countries along the European Union accession process, although such a case may be perceived as a positive case, it cannot be mentioned about a healthy state unless the employment capacities of the other sectors could meet the demands of the migrators from rural parts.

In Turkey, agricultural indicators should be evaluated and positive and negative developments should be assessed meticulously with regard to meet nutritional needs of the public in on hand and to comply with the EU accession criteria and other international norms on the other hand. The production policies, employment policies, price policies, agricultural policies and other social policies to be implemented in the light of these economic indicators are the significant issues for the future of country agriculture. Therefore, the objectives of the present study were set as to assess in detail the changes experienced in agricultural sector of Turkey during the last decade and serve the possible outcomes for the use of policy and decision-makers.

Land use in agriculture was assessed in the second section of this study, amount of productions of the basic agricultural products were evaluated in the third section, machinery use was assessed in the fourth section, share of agriculture in GDP and growth rates were considered in the fifth section, employment-agriculture relationships were evaluated in the sixth section, the share of agriculture in foreign trade was taken into consideration in the eight section and finally agricultural policies implemented in Turkey were provided in the ninth section. During the entire sections, the changes observed in these indicators during the last decade were evaluated. In conclusion section of the study, findings were summarized and recommendations were provided for the future of country agriculture. This study was initially discussed in the International Conference on Eurasian Economies, Skopje, Macedonia, 1-3 July 2014

\section{Material and Method}

Macroeconomic data of Turkish Institute of Statistics and data provided in previous relevant literature constituted the materials of the present study. Among the basic economic indicators, the ones related to agriculture (agricultural land use, production, mechanization levels, share of agriculture in national income, agricultural labor, foreign trade, agricultural production value and agricultural supports) were assessed and the change ratios during the last decade were calculated. The reasons of positive or negative changes were put forth together with supporting literatures and problems of Turkish agricultural sector were identified. Ultimately, solutions were proposed for the possible problems identified in this study.

\section{Land Use in Agriculture}

Turkey has reached the ultimate limits in land use because of rapid increase in population and urbanization. On the other hand, production of food stuff should also be increased parallel to increase in population. Therefore, prevention of misuse of agricultural lands is the critical issue for the future of the agricultural production. Thusly, inefficient and unproductive use of agricultural lands in rural sections makes the poverty inevitable and result in migration of people dealing with agricultural activities (Topçu and Çelik, 2012). In Table 1, product group-based land use of Turkey and the changes observed during the last decade are provided. As it can be seen from the Table, total agricultural lands of Turkey are 38.428 thousand hectares. Of this total, $41 \%$ is cultivated lands, $38 \%$ is pasture and meadows, $11 \%$ is fallow lands, $8 \%$ is orchards and $2 \%$ is vegetable production lands. Considering the changes observed during the last decade, there was $5 \%$ decrease in total agricultural lands, $10 \%$ decrease in cultivated lands, $17 \%$ decrease in fallow lands and $11 \%$ decrease in vegetable production lands. On the other hand, while there was 19\% increase in orchard lands, the size of pasturemeadow lands did not change. Global climate crisis and cyclical fluctuations in international markets especially after the year 2005 triggered the migrations from rural sections and resulted in decreases in cultivated lands. Land uses, small sizes and scattered structure of agricultural enterprises negatively affect the production in Turkey. According to agricultural census of the year 2001, number of enterprise is 3.1 million and they mostly have 4-5 pieces of land. Average enterprise size is around 6 ha and such a value is almost one-third of EU averages (Taşdan et al., 2008).

Table 1. Year-based Agricultural Land Use (1000 ha) Source: Turkish Statistics Institute (TUIK)

\begin{tabular}{|c|c|c|c|c|c|c|c|}
\hline Years & Total & Cultivated Land & Fallow Land & Vegetable & Ornamental Plants & Fruit & Pasture-Meadow \\
\hline 2003 & 40.644 & 17.408 & 4.991 & 911 & & 2.717 & 14.617 \\
\hline 2005 & 41.223 & 18.005 & 4.876 & 894 & & 2.831 & 14.617 \\
\hline 2007 & 39.505 & 16.945 & 4.219 & 815 & & 2.909 & 14.617 \\
\hline 2009 & 38.911 & 16.217 & 4.323 & 811 & & 2.943 & 14.617 \\
\hline 2011 & 38.231 & 15.692 & 4.017 & 810 & 4 & 3.091 & 14.617 \\
\hline 2013 & 38.428 & 15.618 & 4.148 & 808 & 5 & 3.232 & 14.617 \\
\hline Change (\%) & -5 & -10 & -17 & -11 & & 19 & 0 \\
\hline \multicolumn{7}{|c|}{589} \\
0
\end{tabular}




\section{Agricultural Production}

\subsection{Cereal Production}

Considering the position and significance of agriculture in country economy, it can be stated that the primary function of agriculture was to meet the nutritional needs of the people. On the other hand, the share of plant and animal production in total production are the significant issues for the economy of the country. Cereals constitute about $75 \%$ of the total cultivated lands of Turkey. According to data of Turkish Statistics Institute (TUIK) of the year 2013, there was 15\% decrease in wheat cultivated lands, 20\% decrease in barley, 29\% decrease in cotton and $8 \%$ decrease in sugar beet cultivated lands. On the other hand, there was $18 \%$ increase in maize cultivated lands and $12 \%$ increase in sunflower cultivated lands. Based on changes in cultivated lands, the change in cereal cultivated lands during the last decade is provided in Table 2. As it can be seen from the Table during the last decade, there was $111 \%$ increase in maize production, $90 \%$ increase in sunflower, $31 \%$ in sugar beet and $16 \%$ in wheat production of Turkey. On the other hand, there was $4 \%$ decrease in cotton production and $2 \%$ decrease in barley production of Turkey. Despite the decreasing production lands, the increase in productions was mainly because of technological developments and increased productivity levels in agriculture. The increases in maize and sunflower were primarily resulted from the agricultural policies implemented to meet supply deficits in these products and technological developments in culture of these two products. The decrease in cotton production sites and productions were mainly resulted from the crises experienced in textile industry of Turkey.

Table 2. Year-based Cereal Productions (ton) Source: Turkish Statistics Institute (TUIK)

\begin{tabular}{|c|c|c|c|c|c|c|}
\hline Years & Wheat & Barley & Maize & Sunflower & Cotton (Unseed) & Sugar beet \\
\hline 2003 & 19.000 .000 & 8.100 .000 & 2.800 .000 & 800.000 & 2.345 .734 & 12.622 .934 \\
\hline 2005 & 21.500 .000 & 9.500 .000 & 4.200 .000 & 975.000 & 2.240 .000 & 15.181 .247 \\
\hline 2007 & 17.234 .000 & 7.306 .800 & 3.535 .000 & 854.407 & 2.275 .000 & 12.414 .715 \\
\hline 2009 & 20.600 .000 & 7.300 .000 & 4.250 .000 & 1.057 .125 & 1.725 .000 & 17.274 .674 \\
\hline 2011 & 21.800 .000 & 7.600 .000 & 4.200 .000 & 1.335 .000 & 2.580 .000 & 16.126 .489 \\
\hline 2013 & 22.050 .000 & 7.900 .000 & 5.900 .000 & 1.523 .000 & 2.250 .000 & 16.483 .306 \\
\hline Change (\%) & 16 & -2 & 111 & 90 & -4 & 31 \\
\hline
\end{tabular}

\subsection{Fruit Production}

In Turkey, fruit production is one of the agricultural activities with a recent increasing trend. The reason of such an increase is the fruit diversity and production potential of Turkey. On the other hand, worldwide competitive advantages of Turkey in fruit culture and recent increases in fruit exports to EU countries have positively affected the fruit culture of Turkey. As it can be seen from Table 3 during the last decade, there was $97 \%$ increase in olive production, $43 \%$ increase in orange production, $36 \%$ increase in tea production, $20 \%$ increase in apple production, $14 \%$ increase in hazelnut production and $11 \%$ increase in grape production of Turkey.

Table 3. Year-based Fruit Productions (ton) Source: Turkish Statistics Institute (TUiK)

\begin{tabular}{|c|c|c|c|c|c|c|}
\hline Years & Grape & Apple & Olive & Orange & Hazelnut & Tea \\
\hline 2003 & 3.600 .000 & 2.600 .000 & 850.000 & 1.250 .000 & 480.000 & 869.000 \\
\hline 2005 & 3.850 .000 & 2.570 .000 & 1.200 .000 & 1.445 .000 & 530.000 & 1.192 .004 \\
\hline 2007 & 3.612 .781 & 2.457 .845 & 1.075 .854 & 1.426 .965 & 530.000 & 1.145 .321 \\
\hline 2009 & 4.264 .720 & 2.782 .365 & 1.290 .654 & 1.689 .921 & 500.000 & 1.103 .340 \\
\hline 2011 & 4.296 .351 & 2.680 .075 & 1.750 .000 & 1.730 .146 & 430.000 & 1.231 .141 \\
\hline 2013 & 4.011 .409 & 3.128 .450 & 1.676 .000 & 1.781 .258 & 549.000 & 1.180 .000 \\
\hline Change (\%) & 11 & 20 & 97 & 43 & 14 & 36 \\
\hline
\end{tabular}

\subsection{Vegetable Production}

Despite the positive increases in fruit productions, there were decreases in production of some vegetables in Turkey. The reason for such decreases was the contractions in foreign trade of these vegetables because of non-compliance with the international quality and standards in these vegetables. Productions of some vegetables in Turkey are provided in Table 4. According to Table during the last decade, while there was $20 \%$ increase in tomato production and $9 \%$ increase in 
onion production, there was $8 \%$ decrease in water melon production, $8 \%$ decrease in melon production and $2 \%$ decrease in cucumber production. The increase in tomato and onion productions were depending on changes in domestic demands and the increases in exports of these products also had positive impacts on production of them.

Table 4. Year-based Vegetable Productions (ton) Source: Turkish Statistics Institute (TUiK)

\begin{tabular}{|c|c|c|c|c|c|}
\hline Years & Tomato & Cucumber & Melon & Water melon & Onion \\
\hline 2003 & 9.820 .000 & 1.783 .120 & 1.735 .000 & 4.215 .000 & 1.750 .000 \\
\hline 2005 & 10.050 .000 & 1.745 .000 & 1.825 .000 & 3.970 .000 & 2.070 .000 \\
\hline 2007 & 9.936 .552 & 1.670 .459 & 1.661 .130 & 3.796 .680 & 1.859 .442 \\
\hline 2009 & 10.745 .572 & 1.735 .010 & 1.679 .191 & 3.810 .205 & 1.849 .582 \\
\hline 2011 & 11.003 .433 & 1.749 .174 & 1.647 .988 & 3.864 .489 & 2.141 .373 \\
\hline 2013 & 11.820 .000 & 1.754 .613 & 1.699 .550 & 3.887 .324 & 1.904 .846 \\
\hline Change (\%) & 20 & -2 & -2 & -8 & 9 \\
\hline
\end{tabular}

\subsection{Livestock Production}

While there have been recent decreases in number of animals in Turkey, productions are increasing based on increasing in productivity levels. The changes observed in livestock products of Turkey during the last decade are provided in Table 5. According to Table, the greatest production increase was observed in silk cocoon production (184\%) and it was respectively followed by red meat (110\%), milk (83\%), honey (48\%), hair (33\%) and wool (25\%). Contrary to increases in several livestock products, there was about $50 \%$ decrease in angora production. The primary reason of such a decrease in angora production is decreasing number of angora goats every year. Use of other industrial products instead of angora in textile industry also negatively affected Angora goat productions. On the other hand, increasing livestock implementations within the scope of supports provided to livestock industry positively affected the livestock production activities of the country.

Table 5. Year-based Livestock Productions (ton) Source: Turkish Statistics Institute (TUIK)

\begin{tabular}{|c|c|c|c|c|c|c|c|c|}
\hline Years & Red Meat & Milk & Poultry & Honey & Silk Cocoon & Wool & Hair & Angora \\
\hline 2003 & 366.962 & 10.611 .011 & 872.419 & 69.540 & 169 & 46.456 & 2.741 & 333 \\
\hline 2005 & 409.423 & 11.107 .897 & 936.697 & 82.336 & 157 & 46.176 & 2.654 & 302 \\
\hline 2007 & 575.622 & 12.329 .789 & 1.068 .454 & 73.935 & 125 & 46.752 & 2.536 & 237 \\
\hline 2009 & 412.621 & 12.542 .186 & 1.293 .315 & 82.003 & 136 & 40.270 & 2.002 & 174 \\
\hline 2011 & 776.915 & 15.056 .211 & 1.613 .309 & 94.245 & 151 & 46.586 & 3.062 & 194 \\
\hline 2013 & 915.844 & 17.401 .262 & 1.723 .919 & 89.162 & 134 & 51.180 & 3.570 & 200 \\
\hline change (\%) & 110 & 83 & 180 & 48 & 184 & 25 & 33 & -50 \\
\hline
\end{tabular}

\section{Machinery Use in Agriculture}

Economic optimization is the basic reason of machinery use in agriculture. In economic optimization, the producer targets to improve the yield per unit area or per unit animal and to reduce the costs. Although the recent mechanizations in agriculture are the critical issues in improving production and time productivity, such mechanizations perceived also among the basic reasons of the migrations from rural to urban. The change in number of tractor and combine harvester in Turkey during the last decade is provided in Table 6 . The data revealed that there was $22 \%$ increase in number of tractor and $32 \%$ increase in number of combine harvester.

Table 6. Year-based inventory of tractor and combine harvester. Source: Turkish Statistics Institute (TUIK)

\begin{tabular}{|c|c|c|}
\hline Years & Number of Tractor & Number of Combine Harvester \\
\hline 2003 & 997.620 & 11.721 \\
\hline 2005 & 1.022 .365 & 11.811 \\
\hline 2007 & 1.056 .128 & 12.775 \\
\hline 2009 & 1.073 .538 & 13.360 \\
\hline 2011 & 1.125 .001 & 14.313 \\
\hline 2013 & 1.213 .560 & 15.486 \\
\hline Change (\%) & 22 & 32 \\
\hline
\end{tabular}




\section{Gross Domestic Product and Agriculture}

There has been a relative decrease in share of agriculture within Turkish economy. During the initial years of the Republic, while the share of agriculture in GDP was $42.8 \%$, the ratio decreased to $36.0 \%$ in 1970 s, $25.0 \%$ in 1990 and finally to $13.5 \%$ in the year 2000 (Miran, 2006). When the data in Table 7 presenting the changes observed during the last decade are evaluated, it was seen that the value which was $11.1 \%$ in the year 2003 decreased to $9.0 \%$ in the year 2010. While the growth rate in agriculture was $-2.2 \%$ in the year 2003 , the ratio increased to $3.1 \%$ in the year 2012 with a $5 \%$ growth. During the last ten years, the years 2005 and 2011 had the greatest growth rates in agriculture.

As it was in various other sectors, the economic crises observed in Turkey in different periods had also significant negative impacts on country agriculture. Thusly, while the growth rate of the country after the economic crises of the year 2001 was $-5.7 \%$, the growth rate in agriculture realized as $-8.1 \%$. Similarly, starting in the year 2006, "Global Climate Crisis" resulted in significant changes in world economy in the years 2007-2008. The increasing food prices started in the 2007 and continued until the summer months of 2008, so called "Food Crisis", was replaced by another crisis "Global Financial Crisis" in the last quarter of 2008 (Dellal and Keskin, 2008). Therefore, -7.0\% growth rate in agriculture in 2007 was basically worldwide global crisis.

Table 7. Year-based GDP and Share of Agriculture (with 1987 prices) Source: Turkish Statistics Institute (TUIK)

\begin{tabular}{|c|c|c|c|}
\hline Year & Gross Domestic Product & Sectoral Share (\%) & Growth Rate (\%) \\
\hline 2003 & 8.475 .962 .713 & 11,1 & $-2,2$ \\
\hline 2005 & 8.701 .634 .939 & 10,2 & 6,6 \\
\hline 2007 & 9.275 .243 .584 & 8,6 & $-7,0$ \\
\hline 2009 & 9.393 .296 .070 & 9,8 & 3,7 \\
\hline 2011 & 8.736 .944 .153 & 8,9 & 6,2 \\
\hline 2012 & 9.141 .423 .592 & 9,0 & 3,1 \\
\hline Change (\%) & 25 & -2 & 5 \\
\hline
\end{tabular}

\section{Employment, Labor Costs and Agriculture}

Since the human beings are the creators of economic life, there are significant relationships between population and economy. Population creates a demand for various goods and services to meet our needs in one hand and provided labor supply, a significant component of production, on the other hand (Rehber and Çetin, 1998). Therefore, rural population and employment are the two critical dynamics of economic development. Table 8 presents total employment and share of agriculture in total employment of Turkey. While total employment was 25.5 million people in the year 2013, the agricultural employment was around 6 million people. There was about 30\% increase in total employment during the last decade. On the other hand, the share of agriculture in total employment decreased from 29.1 to $23.6 \%$ with a $5.5 \%$ decrease. Such values indicated higher increases in employment in service and industrial sector than in agricultural sector. The decrease in share of rural population in total population of Turkey was because rural development policies were covering industrial sector and agricultural mechanization has been developing day by day. On the other hand, low producer incomes because of inheritance law-induced land fragmentations have also forced the producers to migrate (Işın et al., 2014).

Table 8. Year-based employment and share of agriculture (1000 people) Source: Turkish Statistics Institute (TUiK)

\begin{tabular}{|c|c|c|c|}
\hline Years & Total Employment (1000 people) & Agricultural Employment (1000 people) & Share of Agriculture (\%) \\
\hline 2003 & 19.632 & 5.713 & 29,1 \\
\hline 2005 & 20.423 & 4.907 & 24,0 \\
\hline 2007 & 21.194 & 5.016 & 23,7 \\
\hline 2009 & 22.594 & 5.683 & 25,2 \\
\hline 2011 & 24.821 & 6.097 & 24,6 \\
\hline 2013 & 25.524 & 6.015 & 23,6 \\
\hline Change (\%) & 30,0 & 5,3 & $-5,5$ \\
\hline
\end{tabular}

On the other hand, wages are lower in the agricultural sector than the other sectors and method of payments are also different in agriculture. Table 9 presents the distribution of wages of seasonal and permanent workers in agriculture 
during the last decade. According to Table, daily payments of seasonal female workers increased from $9 \mathrm{TL}$ to $33 \mathrm{TL}$ during the last ten years with an increase ratio of $252 \%$. Daily payments of seasonal male workers increased from $12 \mathrm{TL}$ to $43 \mathrm{TL}$ with an increase ratio of $259 \%$. While daily payment average of seasonal workers was $11 \mathrm{TL}$ in the year 2003 , the value increased to $38 \mathrm{TL}$ in the year 2013 with an increase ratio of $269 \%$. On the other hand, monthly payment of permanent female workers increased from 232 TL to 858 TL with an increase ratio of $269 \%$. Monthly payment of permanent male workers increased from $306 \mathrm{TL}$ to $1128 \mathrm{TL}$. The average monthly payments of permanent workers increased from 297 TL to 1090 TL with an increase ratio of $267 \%$.

Table 9. Year-based payments of agricultural workers (TL) Source: Turkish Statistics Institute (TUIK)

\begin{tabular}{|c|c|c|c|c|c|c|}
\hline & \multicolumn{4}{|c|}{ Average Daily Payments of Seasonal Workers (TL) } & \multicolumn{3}{|c|}{ Average Monthly Payments of Permanent Workers (TL) } \\
\hline Years & Female & Male & Average & Female & Male & Average \\
\hline 2003 & 9 & 12 & 11 & 232 & 306 & 297 \\
\hline 2005 & 13,62 & 18,06 & 15,34 & 314,41 & 403,49 & 391,49 \\
\hline 2007 & 19,17 & 25,94 & 22,19 & 550,19 & 706,39 & 693,70 \\
\hline 2009 & 22,65 & 32,21 & 27,19 & 650,32 & 835,99 & 806,33 \\
\hline 2011 & 28,52 & 38,41 & 32,91 & 748,14 & 1021,76 & 978,97 \\
\hline 2013 & 33 & 43 & 38 & 858 & 1128 & 1090 \\
\hline Change (\%) & 252 & 259 & 260 & 269 & 269 & 267 \\
\hline
\end{tabular}

\section{Foreign Trade and Agriculture}

Annual import and export ratios of Turkey are increasing in each year. Year-based share of agriculture in foreign trade of Turkey is presented in Table 10. According to International Standard Industry Classification, total import of Turkey increased by $263 \%$ and agricultural import increased by $206 \%$ during the last ten years.

Table 10. Year-based share of agriculture in foreign trade (International Standard Industrial Classification (USSS, Rev.3)) Source: Turkish Statistics Institute (TUIK)

\begin{tabular}{|c|c|c|c|c|c|c|}
\hline Years & $\begin{array}{c}\text { Total Import } \\
(1000 \$)\end{array}$ & $\begin{array}{c}\text { Agriculture } \\
(1000 \$)\end{array}$ & $\%$ & $\begin{array}{c}\text { Total Export } \\
(1000 \$)\end{array}$ & $\begin{array}{c}\text { Agriculture } \\
(1000 \$)\end{array}$ & $\%$ \\
\hline 2003 & 69.339 .692 & 2.537 .855 & 3,7 & 47.252 .836 & 2.201 .436 & 4,7 \\
\hline 2005 & 97.539 .766 & 2.765 .260 & 2,8 & 73.476 .408 & 3.468 .315 & 4,7 \\
\hline 2007 & 139.576 .174 & 2.934 .996 & 2,1 & 107.271 .750 & 3.883 .465 & 3,6 \\
\hline 2009 & 201.963 .574 & 6.433 .040 & 3,2 & 102.142 .613 & 4.536 .473 & 4,4 \\
\hline 2011 & 185.544 .332 & 6.490 .029 & 3,5 & 134.906 .869 & 5.352 .613 & 4,0 \\
\hline 2013 & 251.650 .823 & 7.776 .120 & 3,1 & 151.812 .239 & 5.912 .976 & 3,9 \\
\hline Change (\%) & 263 & 206 & -0.6 & 221 & 169 & -0.8 \\
\hline
\end{tabular}

While the share of agriculture in import was $3.7 \%$ in 2003 , the value decreased to $3.1 \%$ in the year 2013 . On the other hand, export increased by $221 \%$ and agricultural export increased by $169 \%$ during the last decade. While the share of agriculture in export was 4.7 in 2003, the value decreased to 3.9\% in the year 2013. EU countries had the first place in agricultural product exports of Turkey and tomato paste, canned foods, fresh vegetable-fruits and bakery products constituted primary export items.

\section{Agricultural Production Value}

Agricultural production value is a significant indicator in assessment of economic changes in agriculture. The agricultural production value and the share of plant and livestock productions during the last ten years are presented in Table 11. Agricultural production value increased by $194 \%$ from 2003 to 2013 . While the share of plant production in agricultural production value decreased from $59 \%$ to $44 \%$, the share of livestock production increased from $41 \%$ to $56 \%$. Such an increase is directly related to changes implemented in livestock policies of the country. 
Table 11. Year-based agricultural production values. Source: Turkish Statistics Institute (TUiK)

\begin{tabular}{|c|c|c|c|}
\hline Years & Agricultural Production Value (Million TL) & Share of Plant Production (\%) & Share of Livestock Production (\%) \\
\hline 2003 & 68.393 & 59 & 41 \\
\hline 2005 & 88.365 & 58 & 42 \\
\hline 2007 & 104.375 & 54 & 46 \\
\hline 2009 & 123.024 & 55 & 45 \\
\hline 2011 & 191.628 & 46 & 54 \\
\hline 2013 & 200.767 & 44 & 56 \\
\hline Change (\%) & 194 & -16 & 16 \\
\hline
\end{tabular}

\section{Change in Agricultural Policies and Supports}

Just because of disadvantaged characteristics, agriculture is among the sectors primary protected by supportive policies in entire countries, especially in developed ones. As it was in entire world, the basic objectives of implemented agricultural policies of Turkey are to increase income and welfare levels of the producers, to provide price stability, to provide consumer welfare through supplying cheap food stuff, to provide self-sufficiency, rural development and currency savings (Tan, 2011).

Together with planned periods, agriculture of Turkey has been protected by various support policies. Since the desired levels have not been reached in agriculture with the current support policies, reforms in policies were pointed out in 7 and $8^{\text {th }}$ Five-year Development Plans. Then with the loan agreements signed with IMF, a new agricultural policy process has been started in Turkey since the years 2000s. All supports provided to producers were gathered under Direct Income Support (DGD) and implemented between the years 2000 and 2008. This support model ended in the year 2008 and then diesel, fertilizer and soil analysis supports, organic farming and good agricultural practices supports, premium supports for sunflower, cotton, soybean-like industrial crops and comprehensive supports for livestock industry were initiated. The supports provided to agricultural sector increased annually. Considering the supports provided during the last decade, while the supports provided to agriculture was 2.80 billion TL in 2003, the value reached to 15 billion TL in the year 2012. On the other hand, total agricultural credits provided by Ziraat Bank and agricultural credit cooperatives increased from 529 million TL to 22.1 billion TL during the last ten years. During this period, a decrease was observed in credit interest rates and an increase was observed in credit returns (GTHB, 2013). The policies for widespread of organic farming and good agricultural practices, development of undercover vegetable production, seed growing policies and gen-source preservation policies are considered as the significant plant production policies. On the other hand, reorganization of EBK (Meat and Fish Authority) and SEK (Milk Industry Authority), zero-interest credits for livestock industry, preservation of gen sources and various breeding policies in livestock industry, supports for forage crops and pasture reclamation works can be counted among the significant livestock policies of the country during the last decade. Again, rural development policies had ever-increasing prominence in each year during the last decade. Substantial amount of supports were transferred to grant projects form national and international sources. These policies were all about to develop agricultural-dependent industries in rural parts of the country.

Beside the above mentioned changes in agricultural policies in Turkey, Agricultural Basins Production and Support Model was among the most significant policies came into force in the year 2010. The model is a practical model composed of five components as of data-base, demand estimation, basin, support and portal. The primary pre-conditions to receive support from this model are the agricultural production activities over the basins and registration to Farmer Registration System (ÇKS) (Karaman and Yavuz, 2012).

\section{Conclusion and Recommendations}

Changes in agricultural economic indicators in Turkey during the last decade were assessed in this study. Results revealed $5 \%$ decrease in total agricultural lands and 10\% decrease in cultivated lands. With regard to products during the last decade, while there was $15 \%$ decrease in wheat cultivated lands, $20 \%$ in barley, $29 \%$ in cotton and $8 \%$ in sugar beet, there was 18\% increase in maize cultivated lands and $12 \%$ increase in sunflower lands. Together with changes in cultivated lands, there was $111 \%$ increase in maize production, $90 \%$ in sunflower production, $31 \%$ in sugar beet and $16 \%$ in wheat production and there was $4 \%$ decrease in cotton production and $2 \%$ decrease in barley production. There was a general increase in fruit productions and a decrease in vegetable productions. As it was in plant production, there was an increase in production of livestock products despite the decrease in number of animals. There was $180 \%$ increase in 
poultry production, $110 \%$ increase in red meat and $83 \%$ increase in milk production. Such increases are pleasing developments. However, such positive developments in poultry and cattle were not observed in sheep.

Together with technological developments, there was $22 \%$ increase in number of tractors and $32 \%$ increase in number of combine harvester. Considering the national accounts, while the share of agriculture in GDP decreased from $11 \%$ to $9 \%$ in ten years, the growth rate of agricultural sector increased from $-2.2 \%$ in 2003 to $3.1 \%$ in 2012 with a $5 \%$ increase. During the last decade, $30 \%$ increase was observed in total employment, but the share of agriculture in total employment decreased from $29.1 \%$ to $23.6 \%$ with a $5.5 \%$ decrease. While the agricultural employment ratios were decreasing, there were significant increases in labor payments. There was around $200 \%$ increase in seasonal and permanent worker payments. The share of agriculture in imports decreased but the share in exports increased. The changes and reforms in implemented agricultural policies came into prominence and supports transferred to agriculture increased from 2.80 billion TL in 2003 to 15 billion TL in 2012.

Considering the agricultural indicators of Turkey in general, there were positive developments during the last decade. But the decreases in cultivated lands and agriculture-dependent employment ratios, together with structural problems of agriculture, have made the agricultural sector less attractive. The increases in productions despite the decreases in cultivated lands were related to developments in technology and productivity levels. Again, increasing livestock products despite the decreasing number of animals indicated the increasing number of productive races in livestock breeding activities.

As to summarize along with the above-provided information, the agricultural policies devoted to preservation and use of agricultural lands, widespread of land consolidation, enlarge the facility and enterprise sizes should be the primary policy issues. A strategy development complying with the European Union Joint Agricultural Policy and a policy allowing the rural people to stay in their own places are also recommended for rural development of the country. Also, within the scope of Basin-Based Support Model, creation of a production pattern complying with the demands of both national and international markets is a highly significant issue for both a planned production and competitiveness.

\section{References}

Cinemre, H.A., Kılıç, O., 2011. Tarım Ekonomisi. Ondokuz Mayıs Üniversitesi Yayınları, Samsun.

Dellal, İ., Keskin, G., 2008. Küresel Mali Kriz: Tarımda Riskler ve Fırsatlar. Tarımsal Ekonomi ve Politika Geliştirme Enstitüsü Yayınları, Anakara.

Erkuş, A., Bülbül, M., Kıral, T., Açıl, F., Demirci, R., 2005. Tarım Ekonomisi. Ankara Üniversitesi Araştırma ve Geliştirme Vakfı Yayınları, Ankara.

GTHB, 2013. 2014 Bütçe Konuşmaları, https://www.google.com.tr/search?q=mehdi+eker+2014+ (Erişim Tarihi: 30.03.2014).

ışın, F., Keskin, G., Kılıç, M., Türkekul, B., Ateş, H.C., 2014. Türkiye'de Tarımsal İşgücü Piyasası ve Sosyal Güvenlik Politikaları. http://www.zmo.org.tr/resimler/ekler/2299f06ee419aa5_ek.pdf (Erişim Tarihi: 10.04.2014).

Karaman, C., Yavuz, F., 2012. "Dünyadaki Eğilimler Işığında Türkiye Tarımsal Destekleme Politikalarının Değerlendirilmesi" 10. Ulusal Tarım Ekonomisi Kongresi Bildiriler Kitabı, Konya, p. 171.

Miran, B., 2006, Türkiye'de Tarım, Tarım ve Köyişleri Bakanlığı, Strateji Geliştirme Başkanlığı Yayınları, Ankara.

Rehber, E., Çetin, B., 1998. Tarım ekonomisi. Uludağ Üniversitesi Güçlendirme Vakfı Yayınları, Bursa.

Tan, S., 2011. "Türkiye'de Uygulanan Tarım Politikaları Kapsamında Çanakkale'nin Mevcut Durumu" Çanakkale Tarımı Sempozyumu Bilidiriler Kitabı, Çanakkale, p.37.

Taşdan, K., Taşdemir, K., Gül, U., Uçum, I., Cebeci, T., Özat, H.E., 2008. Ekonomik Göstergelerle Türkiye'de Tarım. Tarımsal Ekonomi ve Politika Geliştirme Enstitüsü Yayınları, Anakara.

Topçu, P., Çelik, N., 2012. "Yoksulluğun Azaltılmasında Tarım Arazilerinin Etkin Kullanımının Sağlanması", 10. Ulusal Tarım Ekonomisi Kongresi Bildiriler Kitabı, Konya, p. 422.

TUIKK, 2014 . Tarımsal İstatistikler (http://www.tuik.gov.tr/UstMenu.do?metod=temelist), (Erişim Tarihi: 30.03.2014).

TUIK, 2014 . Ulusal Hesaplar (http://www.tuik.gov.tr/UstMenu.do?metod=temelist), (Erişim Tarihi: 30.03.2014).

TUIK, 2014. İşsizlik, İstihdam ve Ücret İstatistikleri (http://www.tuik.gov.tr/UstMenu.do?metod=temelist (Erişim Tarihi: 30.03.2014).

TUIK, 2014. Dış Ticaret İstatistikleri (http://www.tuik.gov.tr/UstMenu.do?metod=temelist (Erişim Tarihi: 30.03.2014). 